\title{
Playing Keroncong Music Using Kolintang
}

\author{
Ardhi Kurniawan ${ }^{1 *}$ Kun Setyaning Astuti ${ }^{2 * *}$ \\ ${ }^{1}$ Art Education of Graduate School, Yogyakarta State University, Yogyakarta, Indonesia \\ ${ }^{2}$ Music Arts Education Yogyakarta State University, Yogyakarta, Indonesia \\ ${ }^{*}$ Corresponding author. Email: ardhikurniawan.2018@student.uny.ac.id \\ ${ }^{* *}$ Corresponding author.Email: kunsetyaningastuti@uny.ac.id
}

\begin{abstract}
Generation $\mathrm{Z}$ in the millennial era tends to be interested in music that utilizes modern technology, and is less interested in Keroncong music. Keroncong is a non-traditional Indonesian music style whose instruments come from Europe. Although the origin of this music is very close to European culture, especially Spain, there is no music style like Keroncong out there. In learning activities, Generation $\mathrm{Z}$ especially those in secondary education have limited access to Keroncong materials. Aside from the younger generation's lack of interest, teachers' and schools' supports for the provision of Keroncong material are considered small. This article is a study of solving the problem of scarcity of keroncong musical instruments replaced with kolintang musical instruments. The role of each Keroncong musical instrument could be replaced by Kolintang.
\end{abstract}

\section{Keywords—S Generation Z, Keroncong, Kolintang}

\section{INTRODUCTION}

Technological advances affect changes in one's taste in music, especially young people whose development is so fast in line with the demands of the times. Generation Z, born after 2001, is in a potential and productive age; they seem to be able to survive and even become the forefront in this millennial era [8]. Advances in technology have an impact on music by popping up alternative choices of new types of music to rival the types of music that previously existed, such as Keroncong music. This type of music seems to only be enjoyed by a few circles, and of course, they are not from Generation $\mathrm{Z}$.

Cultural Arts discusses activities and knowledge in the field of arts taken from Indonesian cultures. This subject should cover materials about Keroncong music because this type of music is a type of original Indonesian music despite being influenced by European culture, especially Spain [2]. Schools as formal institutions that instill knowledge, skills, attitudes, and characters based on local cultures endeavor to preserve Indonesian cultures, including Keroncong music, that are increasingly eroded by the changing times. Some informal communities have begun to realize the value of cultural heritage in this field of music. They try to preserve and develop Keroncong with new models, such as by combining Keroncong with an orchestra, traditional musical instruments, etc. There is even a music group named "Djagank" that combines Keroncong with electric music played by "DJ Nunu" [6]. This effort brings great hope that the younger generation, including students, will like it. The emergence of Keroncong music groups among young people indicates this new hope. However, the role of education through Cultural Arts subjects in schools is still insignificant.

Like what informal communities do, formal education institutions through schools need to play a role in preserving this type of music [4]. Cultural Arts subjects should provide other ways/alternatives in presenting Keroncong music to foster students' interest in. This study found another alternative in playing Keroncong music by using Kolintang musical instruments. This innovation can be an alternative for schools that do not have Keroncong musical instruments but have Kolintang.

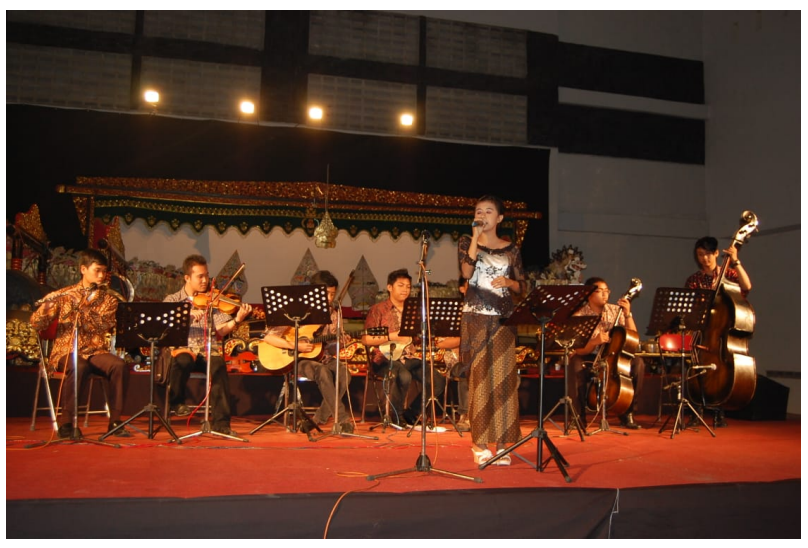

Figure 1 Keroncong performance by the students of SMK N 2 Kasihan, Bantul (Documentation of SMK N 2 Kasihan, Bantul) 


\section{DISCUSSION}

\subsection{Rhythmic Analysis}

The musical instruments in Keroncong are very diverse. The variety of musical instruments is very dependent on the creativity and culture that influence it. This type of music is categorized into a mixed ensemble with musical instruments such as bass, cello, ukulele (cak and cuk), guitar, flute, and violin. This type of music is called 'Keroncong' because one of the instruments, the ukulele, sounds "Crong, Crong" when strummed, so the Kampung Tugu community changed its name to 'Keroncong' '[2]. The followings are the rhythm of each instrument played in Keroncong:

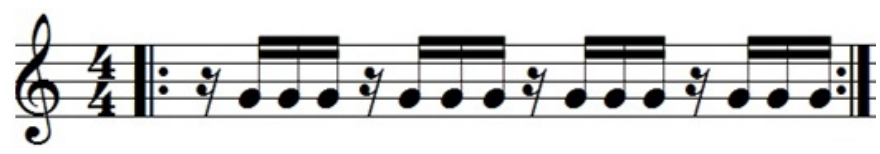

Figure 2 The rhythm of a cuk

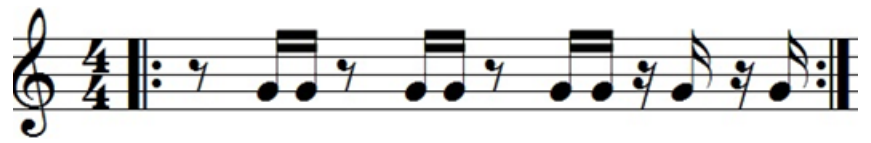

Figure 3 The rhythm of a cak

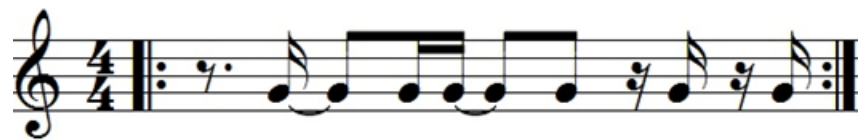

Figure 4 The rhythm of a cello

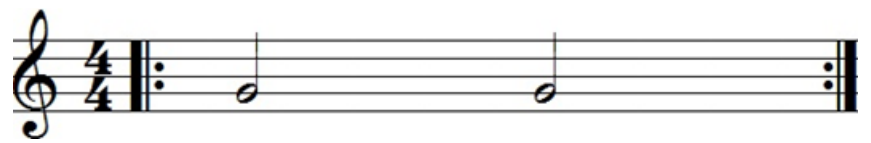

Figure 5 The rhythm of a bass

Although Keroncong and Kolintang are both musical ensembles, Kolintang belongs to homogeneous ensembles. This instrument is a traditional musical instrument from Minahasa, North Sulawesi. Each instrument has a name that is commonly known. In a full set, there are 9 instruments. But for students, 5 Kolintang musical instruments are enough. These instruments include:

a. Melody. It functions as the main focal point of the song. It is just like a melody on a guitar, violin, xylophone, or vibraphone. Even so, because the sound is not long enough, the intended tone must be held by vibrating the stick (roll). Melody players generally use two sticks so that the combination of one of the main melodies is the same as the combination of people singing a duet or trio (if using three sticks). If there are two melodies, they can be used together to make the sound stronger. In that way, the sound produced can match the accompaniment sound (especially in a complete set). Both can also be played by strumming the same note but with a different octave, or one of the melodies plays the main song while the other is for improvisation.

b. Cello. The function of Cello is similar to that of a piano. The right hand on the piano is replaced with a melody, while the left one is replaced with a cello. The left hand on the cello holds the stick no.1 which functions as a bass, while the right-hand functions as an accompanist (stick no.2 and no.3). In playing Keroncong music, it will be easier to use just one stick because the functions of stick no. 2 and no. 3 are already in Tenor and Alto.

c. Tenor and Alto. They function as accompaniment rhythm like a guitar that is used to accompany a song. Kolintang Tenor and Alto have notes in a chord, for example, $\mathrm{C}=1.3$, and 5 (this position can be reversed). This instrument usually has 3 sticks with 2 in the right hand and 1 in the left hand.

d. Bass. It functions just like a bass in a band. Usually, the player uses 2 sticks. The tone played has a pair, which is the 5th note of the chord. For example, the bass of $\mathrm{C}$ chord is $\mathrm{C}$ and is paired with the $\mathrm{G}$ note (the 5 th note from $\mathrm{C}$ ).

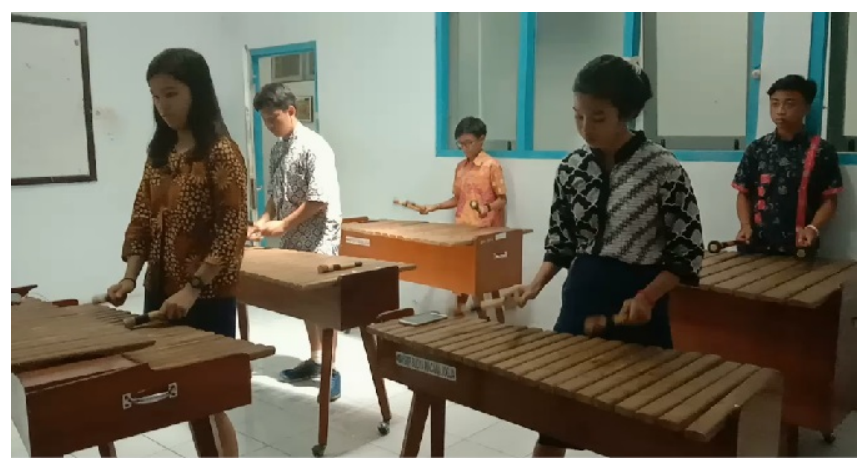

Figure 6 Students are playing Kolintang (Documentation of Cultural Arts class in SMP Budya Wacana)

\subsection{How to hold the Kolintang sticks}

There is no fixed ways when it comes to how to hold a Kolintang stick for it depends on the habits of players. Commonly, stick number 1 is always on the left hand, number 2 and 3 are in the right hand. Stick number 2 is between the thumb and index finger, while stick number 3 is between the middle and ring finger. In a bass and melody, usually only 2 sticks are used, and thus making it easier for the players to hold. These numbers are written in every base of the stick [3].

\subsection{Replacement of Instrument's Roles}

The role of instruments that characterize Keroncong music will be replaced by the Kolintang musical instruments as follows: 
a. Cak is replaced by Kolintang Tenor. In its role as Cak, Kolintang Tenor plays chords using the rhythmic of Cak.

b. Cuk is replaced by Kolintang Alto. Kolintang Alto plays chords with a simple arpeggio on the right hand by taking levels 1 and 3. For example, on the $\mathrm{C}$ chord, the position of the right hand is in notes $\mathrm{C}$ and $\mathrm{E}$, and the left hand is in the note G. The right-hand tone is played alternately according to the rhythm as depicted in Figure 1.

c. Cello is replaced by Kolintang Cello. Unlike other instruments, Cello is more dominantly played with the left hand by playing the chord which is broken down according to the rhythmic shown in Figure 3. For example, for the $\mathrm{C}$ chord, the notes that are drawn are c-c-c-G-G-E-E. This function indicates the outset of Bass at the beginning of each bar. The right hand on Cello plays two notes according to the chords simultaneously and is less dominant than the left hand.

d. Bass is replaced by Kolintang Bass. The rhythms of a bass are very simple because they only exist in the first and third beats. The outset of the bass is marked by the dominant sound of the left hand of Kolintang Cello. The first beat hits the base note, while the third beat hits the fifth note. If in one bar there is a chord change, Bass only hits the first note on the first beat, and on the third beat, Bass hits the first note on the chord that has changed.

e. Melody is replaced by Kolintang Melody. The role of Kolintang Melody in Keroncong music is only as a song melody that is added with some variations and fillers.

\subsection{Learning Methods}

The materials developed in this innovation are procedural skills in playing Kolintang musical instruments which are applied in playing Keroncong music. The materials cover how to hold the stick, the chords used, the sequence/ movement of the chords used in a song being played, as well as the rhythmic parts of the Kolintang musical instrument if applied as musical instruments in Keroncong music. These learning activities train a lot of skills and will be more easily delivered by using the direct learning method by the trainer repeatedly or drilling [7]. This is in line with what is asserted by Paul Eggen and Don Kauchak, stating that the direct learning method is most suitable to be used in teaching procedural skills [1]. Here are the learning phases:

- Introduction and Review. The teacher reinforces the material about the notes in chords I, ii, iii, iv, V7 and how to play them in Kolintang collaboratively. After all students master the chords, the teacher introduces Keroncong through the Bengawan Solo song by playing the song using audio media. Then, the teacher motivates students to be able to play the Keroncong song by using the Kolintang musical instruments. The teacher confirms the position of the Kolintang musical instrument chosen by each student.

- Presentation. In this phase, the teacher explains the basic musical instruments used in Keroncong music, namely Cak, Cuk, Cello, Bass, and Melody. Then, the teacher explains how to apply these instruments by using the Kolintang musical instruments in which Cak is replaced by Kolintang Tenor, Cuk is replaced by Alto, Cello is replaced by Cello, Bass is replaced by Bass, and Melody is replaced by Kolintang Melody. After the explanation, the students listen carefully to the Bengawan Solo song again and analyze the sound and rhythm of each instrument by answering the following question guideline:

a. How is the rhythm of Cak?

b. How is the rhythm of $C u k$ ?

c. How is the rhythm of Cello?

d. How is the rhythm of Bass?

e. How is the rhythm of Melody?

After that, students try to play the five musical instruments in Keroncong using the Kolintang musical instruments. After the rhythm of each instrument appears, the teacher demonstrates in detail how to play Cak, Cuk, Cello, Bass, and Melody in the Bengawan Solo song using the Kolintang musical instruments.

- $\quad$ Guided Practice. In this phase, students try to play the rhythm of Cak, Cuk, Cello, Bass, and Melody by using the Kolintang instruments in accordance with their parts with the $\mathrm{C}$ chord first. The teacher guides students one by one. After all students master their part, the teacher asks them to play the music together while still using the $\mathrm{C}$ chord. The teacher monitors and corrects if there are students who make mistakes or are still confused in playing it. After all students master the instruments, the teacher asks them to play chords G, G7, F, D, and C7 gradually. These chords are the chords needed to play the Bengawan Solo song. After all the chords are mastered, the teacher guides students to play the chord progressions, starting with simple progressions namely $\mathrm{C}$ to $\mathrm{G}, \mathrm{C}$ to $\mathrm{F}, \mathrm{C}$ to $\mathrm{D}$, and $\mathrm{F}$ to $\mathrm{G}$ or G7 (leveled from the easiest to the most complicated one). In addition to the accompanying elements (Tenor, Alto, Cello, and Bass), the teacher also shows how to play the melody with the notation of the Bengawan Solo song. After the song melody is mastered, the teacher guides the students to play one verse of the song together, starting with verse A of the first stanza [5].

Verse A|V7...|I...|IV.V7.|I...|I...|V7...|V7...|I...|

After mastering verse A of the first stanza, the students practice playing verse A of the second stanza, verse B of the refrain, and verse A of the closing stanza respectively.

Verse A’|V7...|I...|IV.V7.|I...II...V7...|V7...I... 
Verse B |I7...|IV...|IV.V.|I...|I...|II...|II...|V ...

Verse A|V7...II...IV.V7.|I...II...|V7 ...|V7 ...|I...|

The intro can be given by playing the last three bars in verse A. Especially for Melody, students learn from the number notation of Bengawan Solo song as depicted in Figure 7:

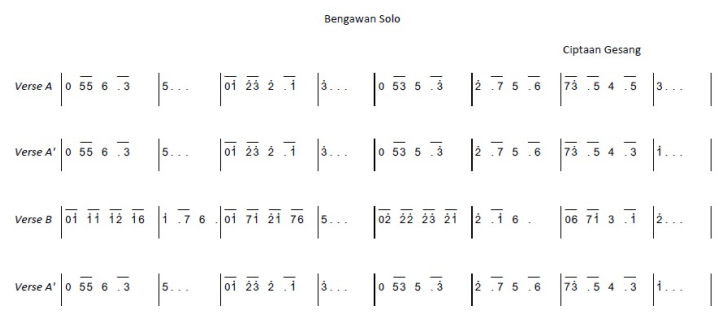

Figure 7 The Number Notation of Bengawan Solo Song

After the students can play the verses well, the teacher guides them to play the Bengawan Solo song from the beginning to the end collaboratively. The teacher acts as a guide and trainer. If there are students who are confused when practicing, the teacher helps and guides them directly. In this process, the teacher still gives verbal guidance when it comes to the chord movement. The teacher mentions the chords that will be played verbally and the students follow the instruction. Gradually, the teacher begins to reduce the verbal instructions and asks the students to feel the chord movements or look at the text to help them. Eventually, the teacher no longer gives verbal guidance until the students are able to practice their skill without any guidance from the teacher.

Students practice independently. But that does not mean leaving them in class, because the teacher keeps monitoring the training process. If there are difficulties and mistakes, the teacher immediately provides correction and guidance. After they can play the song using Kolintang properly, the teacher can give them the opportunity to practice outside of the teaching and learning activities in the classroom.

\section{CONCLUSION}

Cultural Arts teachers as educators must play an active role in efforts to preserve Keroncong as the nation's culture. In its implementation, there are many obstacles encountered, such as the limited number of instruments and lack of support from schools and government agencies. Even so, teachers must be creative and find new innovations in providing Keroncong learning in the classroom, using alternative musical instruments namely Kolintang. It is very likely that other innovations will emerge as a positive impact of teacher creativity. Thus, teacher creativity will continue to increase and Keroncong music can be preserved.

\section{REFERENCES}

[1] Enggen, Paul, and Don Kauchak. "Strategi dan model pembelajaran mengajarkan konten dan keterampilan berpikir [Learning strategies and models teach content and thinking skills]." Diterjemahkan olehSatrio Wahono.(2012). Jakarta: Indeks (2012).

[2] Ganap, Victor. "Pengaruh Portugis pada Musik Keroncong (Portuguese Influence to Kroncong Music) [Portuguese influence on Keroncong music (Portuguese Influence to Kroncong Music)]." Harmonia: Journal Of Arts Research And Education 7.2 (2006). DOI: https://doi.org/10.15294/harmonia.v7i2.753

[3] Kaseke, Petrus. "Buku Panduan Kolintang [Kolintang Handbook]." (2013).

[4] Milyartini, Rita, "Singing Keroncong and the Values Behind It", Advances in Social Science, Education, and Humanities Research, 1st International Converence on Art and Design Education 2018255 (2018). DOI: https://doi.org/10.2991/icade-18.2019.31

[5] Nugroho, Y.S, “Analisis Teknik Permainan Gitar Dalam Irama Keroncong pada HAMKRI Surakarta [Analysis of guitar game techniques in the rhythm of Keroncong in Surakarta HAMKRI]." Universitas Negeri Yogyakarta (2015). URL: http://eprints.uny.ac.id/id/eprint/16896

[6] Rachmasari, V.D., "Kolaborasi Group Keroncong Djagank dan DJ Nunu dalam Arasemen Lagu Bengawan Solo di Kota Lamongan [Collaboration between Keroncong Group Djagank and DJ Nunu in the song of Bengawan Solo in Lamongan]." SOLAH UNESA 8.2 (2018). URL:

https://jurnalmahasiswa.unesa.ac.id/index.php/sola $\mathrm{h} /$ article/view/2953

[7] Saputra, Angga Dika. Strategi Pembelajaran Musik Kolintang pada Grup Bapontar Ladies di Sanggar Bapontar Jakarta [Kolintang Music Learning Strategy on the Bapontar Ladies group at Sanggar Bapontar Jakarta]." Diss. Institut Seni Indonesia Yogyakarta, 2018. URL: http://digilib.isi.ac.id/id/eprint/3082

[8] Al Walidah, Iffah. "Tabayyun di Era Generasi Millenial [Tabayyun in the Millenial generation Era]." Jurnal Living Hadis 2.2 (2017): 317-344. DOI:

https://doi.org/10.14421/livinghadis.2017.1359 